\title{
TONES OF STEVE JOB'S GOODBYE SPEECH
}

\author{
Yena Aulia Rusilawati ${ }^{1}$, Acep Haryudin ${ }^{2}$, Efransyah ${ }^{3}$ \\ ${ }^{1}$ IKIP Siliwangi \\ ${ }^{2}$ IKIP Siliwangi \\ ${ }^{3}$ IKIP Siliwangi \\ ${ }^{1}$ yarusilawati@gmail.com, ${ }^{2}$ haryacep@gmail.com, ${ }^{3}$ efransyahbae@gmail.com
}

\begin{abstract}
This article is an analysis study of tone in a speech, and this analysis based on the theory by Michael McCarthy and Crystal. The article is aimed to know about kinds of tones, the dominant tones and the meaning of dominant tones in the speech. The writers found that this speech used five kinds of tones, namely Rise, Fall, Fall-rise, Rise-fall and level. The result showed all answer of the question. In this article we can know the meaning from the speaker in his speech, how is his feeling and his expression just from their tones in speaking that is Steve job's showed how Steve Job's is Encouragement, Urgency and Straight (positive face) because the dominant types of tone he used in his speech is Fall-rise. In the video showed. The writers suggests for the further writers can use other sources which are more than interesting from this one.
\end{abstract}

Keywords: Speech, Tones

\section{INTRODUCTION}

Language is a tool for interacting and communicating that is useful for delivering thoughts, ideas or feelings. When studying a language, it will not be detached from linguistics. Linguistics is the study of language, how to analize a form of language, the meaning of a language and a language in a particular context. In linguistics we can learn how a language delivered by each individual differently. As with a tones, the tones generated by an individual who is speaking will differ according to the intent of the speaker itself.

Linguist says that "speaking is language", speaking is the capability of language skills that is developed in childhood it is beginning with listening skills. Certainly speaking has close relation with vocabulary development, which is required by children through reading and listening activities. Speaking is communication by speech by arranging the words and sentences that are conveyed orally (Tarigan, 1986, cited in Haryudin, 2016).

According to Fromkin (1972), Linguists, working within the Generative Phonology paradigm, are attempting to establish a theory which defines formally and substantively the phonological components of grammars which will specify all and only the set of possible sound systems of human languages.

Nowadays, English is used in many activities either orally or in written form (Mundriyah and Parmawati, 2016). In an utterance, there are variations of tones that speakers may use in English. Every variations of the tones that a speaker speak in English may be fall, rise or level. Some phonologists distinguish eight different types of tones. But in this study, the writers took only five types of tones to be analyzed. They are Fall, Fall-rise, Rise-fall, Rise and Level. The 
two most frequently tones found in discourse are fall (proclaiming tone) for new information and fall-rise (Referring tone) for given information.

Variations of tones in a speech can often spread itself out over more than one on syllable or word especially the Fall-rise and fall-rise tones. Indeed, it will often be difficult to seperate consecutive occurences of a fall and a rise from a single fall-rise that spreads over several words. However, sometimes the speaker clearly shows the tones.

In addition, Goh (2000) states that tone is a major pitch movement within a tone unit. This movement always begins on the tonic syllable, and. may end on the same syllable or be carried forward into the rest of thetone unit (also referred to as the enclitic segment). Furthermore, Wang (n.d.) claims that tone is always aligned with the syllable it is associated with. This principle may sound simplistic given the vast amount of literature seeming to indicate misalignment of the two. However, as we will show, this discrepancy is mainly due to the work of the basic mechanisms of tone production.

Moreover, Pike (1948) defines a tone language as a language having a lexically significant, contrastive but relative pitch on each syllable. Goldsmith (1982:49) opines that in a tone language, the lexical entry present in a given structure includes (or, conceivably consists simply of) complete tonal melody...." a tone language is that which utilizes tone as a necessary and integral part of every syllable which makes for differences in meaning and marks grammatical distinctions between otherwise identical constructions (Chinwe, 2014).

According to Crystal 1995 cited in Cauldwell 1997 in Attitudinal meanings associated with several tones, namely: Fall which means emotionally involved: surprise, excitement, irritation, Rise means emotionally involved: disbelief, shock and the last is Fall-rise which means a positive face: encouragement, urgency, a straight or negative face: uncertainty, doubt, tentativeness (Cauldwell, 1997).

In line with types of tones by McCarthy 1991 the prominent syllables in an utterance are the carriers of any significant variation in pitch that the speaker might use. At recognisable points in the utterance, the pitch level may rise, fall, or be carefully kept level. Pho- nologists disagree as to the number of discrete types of significant falling, rising and level tones that are used in English; some distinguish between as many as eight, others work with four or five. For our practical purposes five will be a useful number to consider. These are: Fall, Fall-rise, Rise-Fall, Rise and Level (Toolan \& McCarthy, 2006).

Intonation has a grammatical function that is how to say something in correct intonations for things such as question, sentence-tag, subordinate clauses. For example, "yes-no" interrogatives and in a rising tone while wh- are held to be uttered with a fall. Intonation or tone can show a person's expression and emotion as if someone is surprised, the tone becomes a high fall but if he is exciting, the tone becomes Fall-rise. Any emotion can be accompanied by any tone. In essence, each tone has its own role in meaning something delivered by someone. Tones makes the language that is spread to be interesting, meaningful and understandable to the listener. If someone speaks in a voice that tends to be flat, it will lead to a misunderstanding.

In this study, the writers analyzed the tones in "Steve Job's Goodbye Speech" from dvmadeeasy. The research questions in this research are what kinds of tones, the dominant tones, and the meaning of each tones used by "Steve Job's Goodbye Speech" from dvmadeeasy especially dominantly used. The purposes of this research are to know kind of tones, dominant tones, and 
to know the meaning of each tone of voice used in speech delivered by the title. To collecting the data, the instrument used by the author is a video. The procedural of the research are : The writers downloaded a video"Steve Job's Goodbye Speech" from dvmadeeasy on youtube, then, the writter analyzed the video, determined the types of tones used by "Steve Job's Goodbye Speech" and the last the writers analyzed the dominant and the meaning of each tones itself.

\section{METHOD}

In this research, the writers used descriptive qualitative. The design is considered appropriate since it is a method used to describe or analyze the results of the study but not used for make broader conclusions (Sugiyono, 2005) cited in (Apsari, 2017) The object of this research is tone used by the speaker, "Steve Job's Goodbye Speech". He is Steven Paul Steve Jobs. The writers collected the data from the youtube. To collect the data, the instrument used by the author is a video. And the writers used the theory from a book of Discourse Analysis For Language Teachers by Michael McCarthy. The procedures of the research are: downloaded video "Steve Job's Goodbye Speech" from dvmadeeasy on youtube, then the writter analyzed it and determine the type of tones used by "Steve Job's Goodbye Speech". Finally the writers analyzed the dominant and the meaning of each tones itself.

\section{RESULTS AND DISCUSSION}

\section{Results}

Transcript

I'm very happy to be here today with you all and some of you may know about 5 months ago I had a liver transplant. So I know a liver of a mid 20's person who died in a car crash and was generation to donate their organs and I wouldn't be here with such generosity. So, I hope all of us can be as generation elect to become organ donors. I'd like to take a moment and thank everybody in the apple community for the hard feel support I got to. It's really mid light and also especially thank to team cook and the entire exactly team an apple they really rose to the ovation and run the company very ably in difficult period. So, thank you guys. Let's give around us applause. So, I'm particle. I'm back at apple loving every day have it and I'm getting to work with are incredible talented teams to come up with some greats new products for you all in the future. So, it's wonderful. Thank you (Dvmadeeasy, 2011).

Table 1. Kinds of Tones Analysis and the meaning of them

\begin{tabular}{lll}
\hline Tone & \multicolumn{1}{c}{ Transcript } & \multicolumn{1}{c}{ Meaning } \\
\hline Fall-rise & I'm very happy to be here today with you all & Encouragement \\
\hline Fall-rise & $\begin{array}{l}\text { and some of you may know about 5 months ago I had a } \\
\text { liver transplant. }\end{array}$ & Encouragement \\
\hline Fall & $\begin{array}{l}\text { So I know a liver of a mid 20's person who died in a car } \\
\text { crash }\end{array}$ & Surprise \\
\hline Fall & and was generation to donate their organs & Surprise \\
\hline Fall & and I wouldn't be here with such generosity. & Surprise \\
\hline Level & So, I hope all of us can be as generation & - \\
\hline Level & elect to become organ donors. & - \\
\hline Fall-rise & $\begin{array}{l}\text { I'd like to take a moment and thank everybody in the } \\
\text { apple community }\end{array}$ & Encouragement \\
\hline Fall-rise & for the hard feel support I got to. & Encouragement \\
\hline Fall-rise & It's really mid light & Encouragement
\end{tabular}




\begin{tabular}{lll} 
Fall-rise & and also especially thank to team cook & Encouragement \\
\hline Fall-rise & and the entire exactly team an apple & Straight \\
\hline Fall & they really rose to the ovation & Excitement \\
\hline Fall-rise & and run the company very ably in difficult period & Straight \\
\hline Fall-rise & So, thank you guys & Straight \\
\hline Fall-rise & Let's give around us applause. & Encouragement \\
\hline Rise & So, I'm particle & Straight \\
\hline Fall-rise & I'm back at apple & Straight \\
\hline Fall-rise & loving every day have it & Straight \\
\hline Rise & and I'm getting to work & Disbelief \\
\hline Fall-rise & with are incredible talented teams & Straight \\
\hline Fall-rise & to come up with some greats new products & Encouragement \\
\hline Level & for you all in the future & - \\
\hline Fall-rise & So, it's wonderful & Encouragement \\
\hline Fall-rise & Thank you & Straight
\end{tabular}

\section{Discussion}

The results there are transcript and analysis of the video ("Steve Job's Goodbye Speech"). I think the result can answer the research question and the analysis can made us to know why steve job's speech like that. Because the analyze have table (twenty five) there are kind of tone the transcript and meaning. Based on the result above, it is found what the tone used, the dominant tone used, and the meaning of each tone used.

\section{CONCLUSION}

Based on the result of the speech video analysis "Steve Job's Goodbye Speech" the kinds of tones that used in that video are Rise, Fall, Fall-rise, and Level. From the table above mentioned the dominant tones used that is Fall-rise, it can see from the data (Fall-rise : 16, Fall : 4, Level $: 3$, Rise : 2 and Rise-fall : 0 ). And the meaning of dominant tones is positive face because the dominant types of tone he used in his speech is Fall-rise. It line to Crystal 1995 in Attitudinal meanings associated with several tones, namely: Fall which means emotionally involved: surprise, excitement, irritation, Rise means emotionally involved: disbelief, shock and the last is Fall-rise which means a positive face: encouragement, urgency, a straight or negative face: uncertainty, doubt, tentativeness.

\section{ACKNOWLEDGMENTS}

Thank you to Allah S.W.T to give me healthy to finish this research. Thank you to my parents and friend to give me support to finish this article. Writers would like to say the biggest thank you for my article supervisors who always gave writerss support when conducting this research. Also, writers would like to say thank you to IKIP Siliwangi Bandung.

\section{REFERENCES}

Apsari, Y. (2017). The Use of Picture Series in Teaching Writing Recount Text. ELTIN JOURNAL, Journal of English Language Teaching in Indonesia, 5(2), 51-56.

Cauldwell, R. (1997). Tones, Attitudinal meanings, and Context. Speak Out! Newsletter of the IATEFL Pronunciation Special Interest Group, 21, 30-35. https://doi.org/10.1.1.634.5772\&re 
Chinwe, O. E. (2014). Tone In Abankaleke Igbo: An Acoustic Analysis Obianika E. Chinwe, Ebonyi State University, Abakaliki, Nigeria. 2(6), 11-26.

Dvmadeeasy. (2011). Steve Job's Goodbye Speech. Retrieved from Youtube website: https://youtu.be/sJmOP8xpDzA

Fromkin, V. A. (1972). Tone Features and Tone Rules. Studies in African Linguistics, 3(1).

Goh, C. (2000). A Discourse Approach to the Description of Intonation in Singapore English. The English Language in Singapore: Research on Pronunciation, 35-45.

Haryudin, A. (2016). The Students' English Speaking Competence Based on KTSP Curriculum. ELTIN JOURNAL, Vol 4(2), 1-12.

Mundriyah, M., \& Parmawati, A. (2016). Using Think-Pair-Share (Tps) To Improve Students'writing Creativity (A Classroom Action Research In The Second Semester Students Of Stkip Siliwangi Bandung). P2m Stkip Siliwangi, 3(2), 84-91.

Toolan, M., \& McCarthy, M. (2006). Discourse Analysis for Language Teachers (Cambridge Language Teaching Library). In TESOL Quarterly (Vol. 26). https://doi.org/10.2307/3587181

Wang, Q. E. (n.d.). What Can Tone Studies Tell us About Intonation? 337-340. 